\title{
Analysis of the Cytotoxic Effects of Vitamin D3 on Colorectal, Breast and Cervical Carcinoma Cell Lines
}

\author{
Shruthi N ${ }^{1}$, Prashanthkumar MV¹, Venugopalreddy B ${ }^{1}$, Suma MN ${ }^{1}$ and Subba Rao VM ${ }^{1,2 *}$
}

${ }^{1}$ Center of Excellence in Molecular Biology and Regenerative Medicine (CEMR) Laboratory, Department of Biochemistry, Jagadguru Sri Shivarathreeshwara Medical College, Jagadguru Sri Shivarathreeshwara University, Mysuru, Karnataka, India

${ }^{2}$ Special Interest Group in Cancer Biology and Cancer Stem Cells (SIG-CBCSC), Jagadguru Sri Shivarathreeshwara University, Karnataka, India

\begin{abstract}
Although evidences from epidemiological suggested possible involvement of vitamin $D$ in the prevention and treatment of cancers, it is not fully known how vitamin $D$ inhibits cancer cell growth. Recent studies have shown that $1,25-(\mathrm{OH})_{2} \mathrm{D}$ inhibits cancer cell proliferation by binding to vitamin-D receptor (VDR). The vitamin $\mathrm{D}-\mathrm{VDR}$ complex in turn (a) upregulate cell cycle inhibitors p21 and p27; (b) promote apoptosis mediators caspase- 3 and 7, Bad, p53 and PTEN; (c) arrest cells in senescence phase; (d) elevate cell differentiation; and (e) inhibit IGF signaling. Moreover, vitamin $D$ reduces reactive oxygen species (ROS) there by prevents the progression of cancer cells. However, it is currently unknown whether vitamin $D$ induced cancer cell death is mediated by its effect on ROS destroying Nrf2 signaling. In addition, it is also not known whether withdrawal of glucose improves the efficacy of vitamin $D$ as presence of excess glucose promotes ROS in cancer cells. Therefore, first, efficacy of vitamin D for inhibiting the growth of cell lines HCT116, HeLa and MCF-7 was determined. Next, the effect of vitamin D on Nrf2 expression and activity in the presence and absence of glucose was assessed. The data showed that vitamin D inhibited the growth of HCT116, HeLa and MCF-7 cells in a dose dependent manner with more potency toward HCT116. Vitamin D reduced the levels of Nrf2 and NQO1 expression when HCT116 cells were treated in glucose lacking medium. But, despite a significant reduction in cell viability, no change in the Nrf2 expression was observed if the HCT-116 cells were treated with vitamin $D$ dissolved in high glucose $(4.5 \mathrm{~g} / \mathrm{L})$ containing DMEM. Therefore, it is concluded that the cell growth inhibition by vitamin $\mathrm{D}$, observed in the presence of glucose, is not at least mediated by Nrf2 modulation in HCT116 cells.
\end{abstract}

\section{Keywords: Vitamin D; Cancer; VDR; Nrf2; NQO1}

Abbreviations: CYP24A1:1,25-Dihydroxyvitamin $\mathrm{D}_{3}$ 24-Hydroxylase; DMEM:Dulbecco's Modified Eagle Medium; DMSO: Dimethylsulfoxide; FBS: Fetal Bovine Serum; FITC: Fluoresceinisothiocyanate; GAPDH: Glyceraldehyde 3-Phosphate Dehydrogenase; HPLC: High Performance Liquid Chromatography; MAPK: Mitogen-Activated Protein Kinases; NQO1: NAD(P)H Dehydrogenase -Quinone 1; Nrf 2: Nuclear Factor Erythroid 2-Related Factor 2; ROS: Reactive Oxygen Species; SRB: Sulforhodamine B; TCA: Trichloroacetic Acid; TRITC: Tetramethylrhodamineisothiocyanate; VDR: Vitamin D Receptor; VEGF: Vascular Endothelial Growth Factor

\section{Introduction}

Vitamin D is a fat-soluble secosteroid with proven ability to inhibit proliferation of cancer cells and inflammatory reactions [1] . Vitamin D presents in two forms, viz.,Ergocalciferol or vitamin D2 and Cholecalciferol or vitamin D3 [2]. Vitamin D3 is synthesized from7dehydrocholesterol in the skin [2]. Vitamin D status of an individual is influenced by solar radiation, diet and lifestyle [3]. Lack of sufficient quantity of vitamin $\mathrm{D}$ not only causes severe disease such as rickets but also make the individual susceptible for developing cancers [4]. Vitamin $\mathrm{D}$ insufficiency has been reported in the pathogenesis of various carcinomas such as gastric, breast and non-Hodgkins lymphoma [5].

Recent correlative studies measuring the levels of vitamin D in patients suffering from carcinomas of breast and prostate have shown a decreased vitamin D level with advanced disease [2]. However, it is not known whether supplementing vitamin D improves the life span by decreasing the burden of cancer, warranting further studies. In this regard, a study reported supplementation of vitamin D to prevent cancer has investigated [6]. But, randomized clinical trials of adequate size and duration with sufficient concentrations of vitamin $\mathrm{D}$ are still lacking [7].
Mechanistically, vitamin D3 binds to VDR, which in turn activate vitamin Dresponse elements (VDREs), thereby directly control the transcription of target genes that include genes regulating cell cycle arrest, differentiation and angiogenesis [8-10]. Vitamin D also plays a prime role in the regulation of angiogenesis [11]. The active form of vitamin $\mathrm{D}$, down regulates the prostaglandin cascade and enhances VEGF expression [12]. Calcitriol has been involved in the inhibition of Wnt signaling in healthy colonic cells highlighting its cancer preventive action [13]. Many animal and human studies have also shown antitumor effects of metabolically active form ie., 1,25(OH)D3 [14].

Vitamin D3 is a potent antioxidant with a strong ability to prevent cancer cell proliferation [15]. Mechanistically, vitamin D3 destroys cellular ROS thereby limits their availability for rapidly proliferating cancer cells [16]. Molecular studies have demonstrated that vitamin D3 upregulates Nrf2 and its target genes NQO1, GST, GPX, SOD and Catalase thereby destroy cellular ROS [17]. Cancer cells produce unusually high ROS due to incomplete oxidation of glucose and lack of ample supply of oxygen for growing tumor cells. Elevated ROS helps

*Corresponding author: Subba Rao VM, Professor, Cellular and Molecular Biology, Center of Excellence in Molecular Biology and Regenerative Medicine (CEMR) Laboratory, Department of Biochemistry, Jagadguru Sri Shivarathreeshwara Medical College, Jagadguru Sri Shivarathreeshwara University, Mysuru - 570015 Karnataka, India, Tel: +91-810-527-8621; E-mail: madhunapantulas@yahoo.com; mvsstsubbarao@jssuni.edu.in

Received: March 14, 2017; Accepted: April 17, 2017; Published April 20, 2017

Citation: Shruthi N, Prashanthkumar MV, Venugopalreddy B, Suma MN, Subba Rao VM (2017) Analysis of the Cytotoxic Effects of Vitamin D3 on Colorectal, Breast and Cervical Carcinoma Cell Lines. Biochem Anal Biochem 6: 318. doi: 10.4172/2161-1009.1000318

Copyright: $\odot 2017$ Shruthi N, et al. This is an open-access article distributed under the terms of the Creative Commons Attribution License, which permits unrestricted use, distribution, and reproduction in any medium, provided the original author and source are credited. 
to trigger cell proliferation by inhibiting cell cycle inhibitors as well as promoting mitogenic substances [18]. Therefore inhibiting ROS production is likely to reduce cancer cell proliferation [19]. Many Nrf2 activators, especially compounds such as curcumin, resveratrol, pterostilbene and phenethylisothiocyanate (PEITC) have been shown to retard cancer cells growth through Nrf2 activation followed by ROS down regulation [20].

To address whether vitamin D3 induced cancer cell growth is also mediated through the activation of Nrf2, we have tested the effect of vitamin D3 on cell proliferation in the presence of high glucose (more ROS) and no glucose (Low ROS) and compared the cell growth inhibition data with Nrf2 and its target gene NQO1 expression and activity levels. The data demonstrated that vitamin D3 inhibited cancer cells proliferation irrespective of whether the cells are grown in media containing glucose or no glucose. However, interestingly, vitamin D3 treatment reduced $\mathrm{Nrf} 2$ when the cells were grown in media containing no glucose suggesting that the cell growth inhibition by vitamin D3 is mediated by mechanisms other than Nrf2 modulation when the cells were cultured and treated in glucose containing medium, but, in the absence of glucose during treatment, the inhibition of cell proliferation is partly mediated by Nrf2 down regulation. However, further studies are required to delineate the mechanisms leading to these differential effects of vitamin D3 on Nrf2 signaling.

\section{Materials and Methods}

\section{Cell culture}

Cell lines representing colon (HCT-116), cervix (HeLa) and breast (MCF-7) were procured from NCCS, Pune, Maharashtra, India. The cells were grown in DMEM supplemented with $10 \%$ FBS, 1\%Glutamaxand 1\% Penicillin-Streptomycin(from Life Technologies, Carlsbed, USA) by incubating in a carbondioxide incubator maintained at $37^{\circ} \mathrm{C}$ and $95 \%$ relative humidity. For determining the cytotoxicity of vitamin D3, $1 \times 10^{4}$ cells in $100 \mu \mathrm{L}$ medium per well were seeded in 96-well plates and the cells allowed growing to $70 \%$ to $80 \%$ confluence [21]. Exponentially growing cells were treated with increasing concentrations of vitamin D3 for $24 \mathrm{~h}, 48 \mathrm{~h}$ and $72 \mathrm{~h}$. All cytotoxicity studies were carried out 3 times with at least 4 replicate wells in each experiment. Average percentage inhibition was calculated by comparing with vehicle DMSO treated cells and the data plotted against concentration. The bars indicate the standard error (SE).

\section{Viability assessment}

Sulforhodamine-B (Sigma Chemical Company, St. Louis, USA) assay was usedto determine the cell viability as described by Skehan et al. [22]. Experimentally we can follow:

Step 1: Fixation of cells: Control and treated cells were fixed in $1 / 4^{\text {th }}$ volume of cold $50 \%(\mathrm{w} / \mathrm{v})$ TCA for $4^{\circ} \mathrm{C}$.

Step 2: Removal TCA and serum proteins: After $1 \mathrm{hr}$ the media was removed and the wells washed with water $(200 \mu \mathrm{L} \times 4$ times $)$ to remove TCA and serum proteins.

Step 3: Staining of cells with SRB: The dried wells were incubated with $100 \mu \mathrm{L} 0.4 \%$ SRB for 30 minutes to stain the cellular proteins, and washed quickly with $1 \%$ acetic acid $(200 \mu \mathrm{L} \times 4$ times) to remove unbound SRB.

Step 4: Solubilization and OD measurement: The bound SRB was solubilized in $10 \mathrm{mM}$ Tris base $(100 \mu \mathrm{L} /$ well $)$ and the absorbance measured at $565 \mathrm{~nm}$ in a multimode plate reader (Perkin Elmer 2300).
The plate background value was measured at $690 \mathrm{~nm}$, and deducted from the $565 \mathrm{~nm}$ readings for calculating the net optical density.

Step 5: Determination of percentage growth inhibition and IC50 values: Percentage growth inhibition was calculated using the following formula:

$\%$ Growth inhibition $=[(\mathrm{OD}$ of vehicle treated cells $-\mathrm{OD}$ of vitamin $\mathrm{D}$ treated cells)/OD of vehicle treated cells] $\times 100$

The IC-50 value was calculated from the plot of inhibition (\%) VS concentration of vitamin D3 using GraphPad Prism [23].

\section{Determination of cellular uptake of vitamin D}

$1.5 \times 10^{6}$ HCT116 cells were allowed to grow in $100 \mathrm{~mm}$ Petri plates for $48 \mathrm{~h}$, and treated with $16 \mu \mathrm{M}$ vitamin D3 for $48 \mathrm{~h}$. The medium was collected and proteins precipitated using HPLC grade methanol. The precipitated proteins were separated by centrifugation at $16,000 \mathrm{rpm}$ for 10 minutes, and $20 \mu \mathrm{L}$ supernatant injected to HPLC equipped with C18 column $(4.60 \times 250 \mathrm{~mm})$. The elution of vitamin D3 was carried out using HPLC grade methanol $(1.0 \mathrm{~mL} / \mathrm{min})$ and the eluted compound detected using a UV detector operating at 270 $\mathrm{nm}$ wavelength. Standard graph was prepared using $5.0 \mu \mathrm{M}, 10.0 \mu \mathrm{M}$, 15.0 $\mu \mathrm{M}, 25.0 \mu \mathrm{M}, 50.0 \mu \mathrm{M}$ and 100.0 $\mu \mathrm{M}$ vitamin-D3 (Sigma Chemical Co, St Louis, USA) and the amount present in the media calculated. Cellular uptake was calculated by deducting the amount present in the supernatant from the total amount used for treatment. Data from three independent experiments was considered for plotting the graph.

\section{Determination of apoptosis}

Apoptosis detection using acridine orange and ethidium bromide staining method was carried out as described by Shailasree et al. 2015 [24]. In brief, $0.3 \times 10^{6} \mathrm{HCT}-116$ cells in $2.0 \mathrm{~mL}$ DMEM supplemented with $10 \%$ FBS per well were plated in a 6 -well plate and after $\sim 24 \mathrm{~h}$ exposed to increasing concentrations of vitamin D3 (10 $\mu \mathrm{M}, 20 \mu \mathrm{M} .40$ $\mu \mathrm{M})$ for $24 \mathrm{~h}$. The control and treated cells were trypsinized and mixed thoroughly to obtain a single cell suspension. Trypsin was neutralized by the addition of complete medium and $20.0 \mu \mathrm{L}$ cell suspension was incubated with $10.0 \mu \mathrm{L} 100.0 \mu \mathrm{g} / \mathrm{mL}$ ethidium bromide and $10.0 \mu \mathrm{L}$ of $100.0 \mu \mathrm{g} / \mathrm{mL}$ acridine orange mixture for 15.0 minutes. Oxaliplatin $(100 \mu \mathrm{M})$ served as positive control. The stained cells were imaged using the fluorescence microscope using TRITC and FITC filters. The images obtained using 2 different channels were later merged to obtain a combined image exhibiting green (live) and orange (apoptotic) cells. At least 5.0 different fields were considered for quantifying the live and apoptotic cells and the percentage apoptosis estimated [24].

\section{Real Time-PCR}

Isolation of total RNA from cells: Total RNA from cultured cells was isolated using Trizol (Guanidiniumisothiocyanate-PhenolChloroform mixture) method as described in Chomczynski et al. [25]. In brief, confluent cells were washed with PBS and total RNA extracted using Trizol reagent by following the steps described below

1. Pelleted $3-5 \times 10^{6}$ cells by centrifugation at $2500 \mathrm{rpm}$ for 10 minutes and added $300 \mu \mathrm{L}$ Trizol.

2. Mixed well by vortexing for $1 \mathrm{~min}$ and next added $60.0 \mu \mathrm{L}$ of chloroform

3. Mix the solution by twining up and down for 25-30 times. Next, the solution was incubated for 2 min at room temperature and centrifuged the content at $10000 \mathrm{rpm}$ for $10 \mathrm{~min}$ 
Citation: Shruthi N, Prashanthkumar MV, Venugopalreddy B, Suma MN, Subba Rao VM (2017) Analysis of the Cytotoxic Effects of Vitamin D3 on Colorectal, Breast and Cervical Carcinoma Cell Lines. Biochem Anal Biochem 6: 318. doi: 10.4172/2161-1009.1000318

Page 3 of 7

4. Using pipette, top aqueous layer containing RNA was collected and transferred to a new, labeled $1.5 \mathrm{~mL}$ microcentrifuge tube.

5. Next, $150.0 \mu \mathrm{L}$ of isopropanol was added to the aqueous layer and incubated for $10 \mathrm{~min}$ at room temperature.

6. The solution was centrifuged at10000 rpm for $10 \mathrm{~min}$, and the supernatant removed.

7. At this point, $500 \mu \mathrm{L}$ of $70 \%$ ethanol was added, mixed well and spun down for $5 \mathrm{~min}$ at $10000 \mathrm{rpm}$

8. Next, the alcohol was decanted and pellet air dried for 2-3 min in laminar hood.

9. The dried pellet was dissolved in 30-50 $\mu \mathrm{L}$ nuclease free water and quantityof RNAmeasured using spectrophotometer operating at $260 \mathrm{~nm}$ and $280 \mathrm{~nm}$.

\section{The RNA was stored at $-80^{\circ} \mathrm{C}$ for subsequent usage}

The quality of isolated RNA was checked using $1 \%$ bleach agarose gel by measuring the ratio between $28 \mathrm{~S}$ and $18 \mathrm{~S}$ bands [25]. Quality of isolated RNA is rated good if the ratio between $28 \mathrm{~S}$ to $18 \mathrm{~S}$ bands is $2: 1$.

Bleach gel electrophoresis: Agarose gel (1\%) was prepared by mixing lgram of agarose in $100 \mathrm{~mL} 1 \mathrm{X}$ TAE buffer $(40 \mathrm{mM}$ Tris pH7.6; $20 \mathrm{mM}$ Acetic acid and $1 \mathrm{mM}$ EDTA) containing $600.0 \mu \mathrm{L} 5 \%$ sodium hypochlorite. The reaction mixture was incubated for $5-10$ minutes at room temperature, and the solution heatedin a boiling water bath until the agarose dissolve. To the melted solution ethidium bromide, at a concentration of $0.5 \mu \mathrm{g} / \mathrm{mL}$, was added. The samples ( 24 $\mu \mathrm{L})$ were electrophoressed by applying 100 volts $(1-5$ volts $/ \mathrm{cm})$ for a period of $60 \mathrm{~min}$. The separated RNA was visualized by exposing to UV light in a UV-transilluminator (Syngene Gel Documentation Unit). The quality of isolated RNA is rated good if the ratio between $28 \mathrm{~S}$ to $18 \mathrm{~S}$ bands is $2: 1$ [25].

Preparation of cDNA: The reverse transcription reaction was performed using the High-Capacity cDNA Reverse Transcription Kit (Life Technology), in a final volume of $20 \mu \mathrm{L}$ containing $1 \mu \mathrm{g}$ of total RNA, 100ng of random hexamers, $2 \mu \mathrm{L}$ reverse transcription buffer, $2.5 \mathrm{mM} \mathrm{MgCl}, 1 \mathrm{mM}$ dNTP, $20 \mathrm{U}$ of Superscript reverse transcriptase, and nuclease free water. Following conditions were used to synthesize cDNA:

\section{Step-1: $25^{\circ} \mathrm{C}$ for $10 \mathrm{~min}$;}

Step-2: $37^{\circ} \mathrm{C}$ for $120 \mathrm{~min}$;

Step-3: $85^{\circ} \mathrm{C}$ for $5 \mathrm{~min}$;

Step-4: $4^{\circ} \mathrm{C}$.

After cDNA synthesis $80 \mu \mathrm{L}$ of nuclease free water was added to obtain a final concentration of $10 \mathrm{ng} / \mu \mathrm{L}$ cDNA.

Quantitative real-time PCR analysis (Q-PCR): All the primers were purchased from Sigma Chemical Company, Bengaluru, Karnataka, India. RT-PCR experiment was performed using the Qiagen Rotor Gene-Q system and the relative fold change determined using the method described by Livak, et al. [26].

Quantification of human NRF2 and NQO1 was performed by using DyNAmo Color Flash SYBR Green QPCR Kit (Finnzymes) by following manufacture instructions. Experimentally, first, the reaction mixture, in a total volume of $20 \mu \mathrm{L}$, containing $50 \mathrm{ng}$ of template cDNA and primers was prepared in each tube. The samples were analyzed in duplicates to determine the reproducibility.
In summary, the RT-PCR reaction mixture contains:

1. SYBR green dye $-10 \mu \mathrm{L}$

2. Primers: Forward- $0.2 \mu \mathrm{M}$; Reverse $-0.2 \mu \mathrm{M}$

3. Templete: $50 \mathrm{ng}$

4. Nuclease free water (require to become $20 \mu \mathrm{L}$ )

Primers for NRF2 (According to Zou, X. et al.) [27]

Forward Primer: TTCAGCAGCATCCTCTCCACAG

Reverse Primer: GCATGCTGTTGCTGATACTGG

Primers for NQO1 (According to Seng et al.)[28]

Forward Primer: TGCAGCGGCTTTGAAGAAGAAAGG,

Reverse Primer: TCGGCAGGATACTGAAAGTTCGCA

Primers for GAPDH (Internal control for normalization) (According to Lister et al.) [29]

Forward Primer: CGACCACTTTGTCAAGCTCA

Reverse Primer: AGGGGAGATTCAGTGTGGTG

\section{Results and Discussion}

\section{Vitamin D3 retarded the growth of cell lines representing car- cinomas of colon and rectum, breast and cervix}

Anti-proliferative activity of vitamin D3 was determined by treating cancer cell lines (HCT 116, MCF-7 and HeLa) with increasing concentrations of vitamin D3 for $24 \mathrm{~h}, 48 \mathrm{~h}$ and $72 \mathrm{~h}$, followed by counting the number of viable cells using SRB assay as described in Materials and Methods. The percentage inhibition compared to DMSO was calculated and plotted against the concentration of vitamin D3. The data showed an increase in the percentagegrowth inhibition as the concentration of vitamin D3 increases (Figure 1). Among the three cancer cell lines tested HCT-116 found more susceptible for vitamin D3 treatment compared to HeLa and MCF-7.

For example, $50 \%$ growth inhibition was observed at $50 \mu \mathrm{M}$ concentration for HCT116 cell line at all time points, however, for HeLa and MCF-7 cell lines an about $1250 \mu \mathrm{M}$ concentration was required to yield $50 \%$ growth inhibition (Figure 1).

\section{Vitamin D3 is taken up by cancer cells}

In order to determine theamount of vitamin D3 taken up by cancer cells, HCT116 cells, which responded to vitamin D3 treatment, were treated with $40 \mu \mathrm{M}$ vitamin D3 for $48 \mathrm{~h}$ and levels in media measured using HPLC. The percentage recovery of vitamin D3 from serum containing medium was assessed as vitamin $\mathrm{D}$ is known to adhere to serum proteins [30]. Results of recovery analysis yielded, reproducibly, $\sim 56 \%$ indicating the binding of $\sim 44 \%$ vitamin D3 to proteins present in the serum (Figure 2). Considering this recovery percentage using the extraction procedure detailed in materials and methods, the data showed in Figure 2 indicate that HCT116 cells have taken $\sim 43 \%$ of vitamin D3 added to the medium (translating to about $17.2 \mu \mathrm{M}$ in cells). Further increase in the vitamin D concentration in the medium did not change the levels of vitamin $\mathrm{D}$ taken up by the cells (data not shown). This could be one reason why no major increasein percentage growth inhibition occurred with further raise in the concentration of vitamin D3 (Figure 2). Variations in response of each cell line to vitamin D3 treatment could be due to differences in the ability of each cell line to up take vitamin D3, which requires further studies. 
HCT-116

(Colorectal Carcinoma Cell Line)

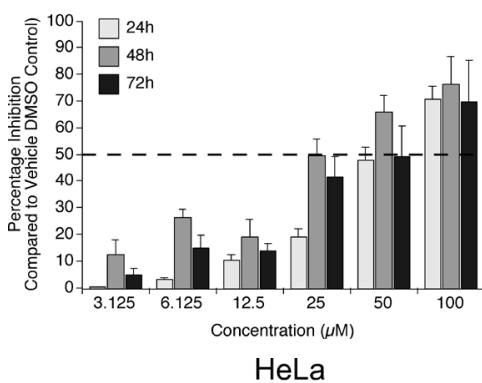

(Cervical Carcinoma Cell Line)

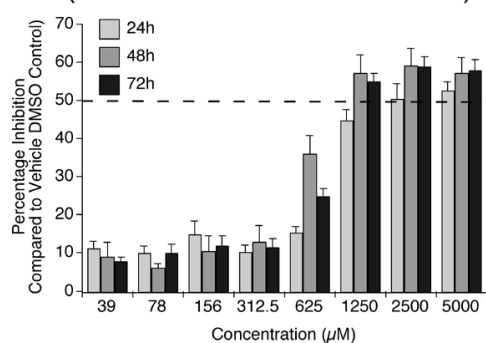

MCF-7

(Breast Carcinoma Cell Line)

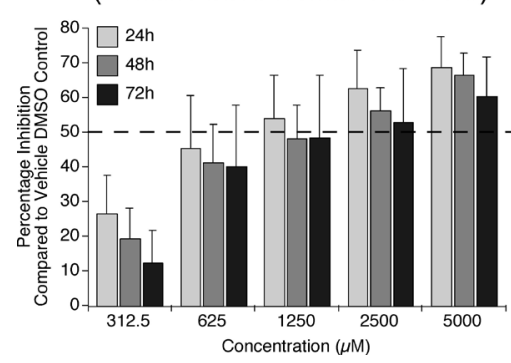

Figure 1: Vitamin D3 inhibited cancer cell growth in a time and dose dependent pattern: HCT116, MCF-7 and HeLa cells were treated with increasing concentrations of vitamin D3 for $24 \mathrm{~h}, 48 \mathrm{~h}$ and $72 \mathrm{~h}$ and viability of cells determined using SRB. The data showed that HCT116 cells are more sensitive to vitamin D3 treatment compared to MCF7 and HeLa cells.
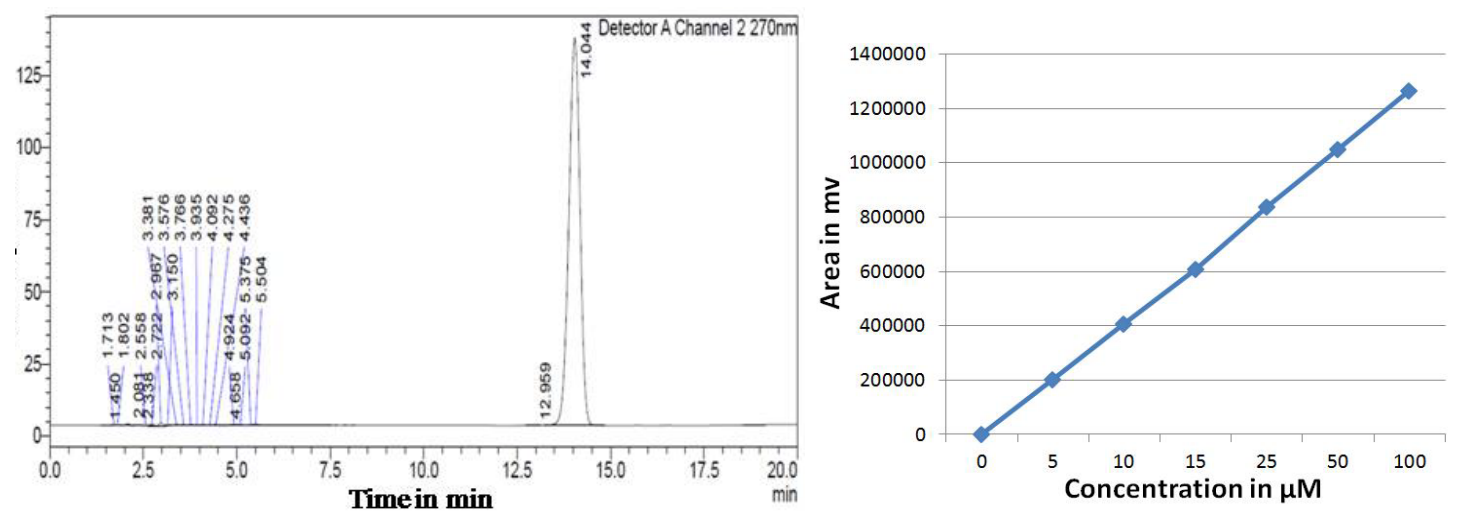

Figure 2: Elution profile and concentration curve of vitamin D3: Analysis of vitamin D3 using HPLC showed a symmetrical peak with 98.5\% of total area indicating that the vitamin D3 utilized in this study is pure. A linear concentration curve obtained using pure vitamin D3 showed the feasibility to determine the concentrations in the range of $1.0 \mu \mathrm{M}$ to $100 \mu \mathrm{M}$. The data represented in concentration curve graph is the average of 3 independent experiments.

Vitamin D3 induced apoptosis in HCT-116 cells: In order to determine the processes affected by vitamin D3 treatment, the levels of apoptosis were estimated using acridine orange and ethidium bromide staining as detailed in materials and methods. The data showed a dose dependent increase in apoptosis as evidenced by the presence of small and shrunken cells with orange staining (Figure 3). However, no such cells were observed in untreated or vehicle $1 \%$ DMSO treated cells. The positive control Oxaliplatin also induced significant apoptotic cell death in HCT116 cells (Figure 3).

\section{Vitamin D3 inhibited Nrf2 expression and activity in a glu- cose dependent manner}

Based on prior studies vitamin D3 is known to stabilize the master antioxidant regulator Nrf2 in cells thereby protect cells from oxidative stress induced damage [31]. However, cancer cells experience more oxidative stress as they primarily use glucose as the source of energy and carbons, and incomplete oxidation of glucose is known to produce very high levels of reactive oxygen species [32]. Therefore, it has been predicted that cancer cells express more Nrf2 and inhibition of Nrf2 by pharmacological agents retard the growth of cancer cells. To test this, Nrf2 expressing HCT116 cells were treated with increasing concentrations $(1 \mu \mathrm{M}, 10 \mu \mathrm{M}$ and $50 \mu \mathrm{M})$ of vitamin D3 for $6 \mathrm{~h}$ in the presence or absence of glucose and levels of Nrf2 and NQO1 measured. The data showed a $35 \%$ decrease in Nrf2 expression at 50 $\mu \mathrm{M}$ concentration, which resulted in about $75 \%$ decrease in NQO1 mRNA only when the cells were grown in media containing no glucose. However at $1.0 \mu \mathrm{M}$ and $10 \mu \mathrm{M}$ concentration no major changes in Nrf2 expression was observed, but a significant 40 to $70 \%$ decrease in NQO1 was noticed only in the absence of glucose. But, in the presence of glucose minor decrease in Nrf2 and NQO1 was observed only at $1.0 \mu \mathrm{M}$ but not at $10.0 \mu \mathrm{M}$ and $50.0 \mu \mathrm{M}$. Variations in the effect of vitamin $\mathrm{D}$ on Nrf2 and NQO1 expression in the presence and absence of glucose 

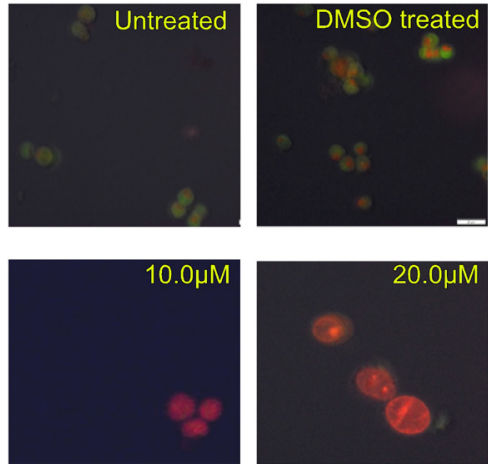

Vitamin D3 24h treatment
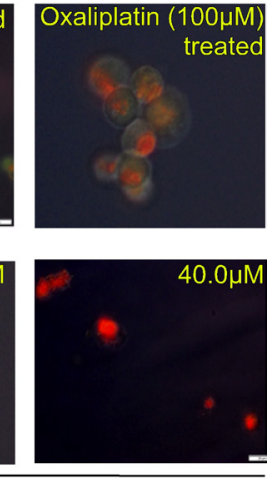
Figure 3: Vitamin D3 induced apoptosis in HCT-116 cells: HCT116 cells were treated with increasing concentration (10 $\mu \mathrm{M}, 20.0 \mu \mathrm{M}$ and $40.0 \mu \mathrm{M})$ vitamin D3 for 24
$\mathrm{~h}$ and stained with acridine orange and ethidium bromide as detailed in materials and methods. Cells stained red represent the ones undergoing apoptosis. Compared to control untreated or vehicle DMSO treated cells, vitamin D3 treated cells showed more number of apoptotic cells. Oxaliplatin (100 $\mu \mathrm{M})$ served as a positive control in this experiment.

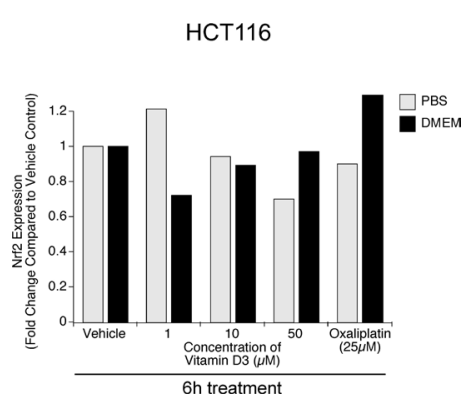

HCT116

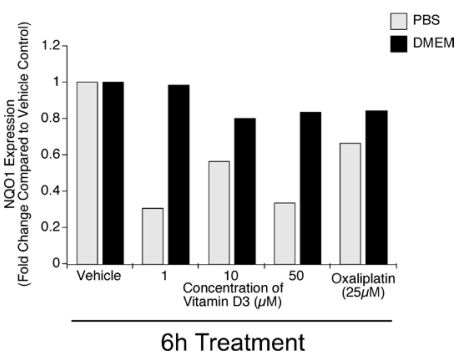

Figure 4: Analysis of the expression of Nrf2 and NQO1 using real time PCR. In order to determine the changes in Nrf2 and NQO1 expression upon treatment of HCT116 cells with increasing concentration of vitamin D3, total RNA was isolated by triazole reagent as detailed in materials and methods and cDNA synthesized. RT$\mathrm{PCR}$ analysis showed a significant decrease in Nrf2 at $50 \mu \mathrm{M}$ vitamin D3 only when the medium is PBS. A significant decrease was also observed in NQO1 expression levels even with $1 \mu \mathrm{M}$ vitamin D3 indicating its more selectivity toward NQO1 compared to Nrf2. Results are the average of two independent experiments with 3 replicate measurements in each experiment.

indicate that vitamin D helps in the stabilization of Nrf2 when there is a need as observed in the glucose-containing medium, but inhibit the expression of Nrf2 when there was no such demand.

\section{Discussion}

Results from various recent reports that include (a) correlative studies measuring and comparing the levels of vitamin $\mathrm{D}$ in cancer patients with disease severity; (b) preclinical studies determining the effect of administering vitamin $\mathrm{D}$ on tumor development have suggested the therapeutic potential of this cholesterol derived sunvitamin for treating cancers [33]. These studies have primarily focused on findings from population-based data and xenografted tumor models, hence, not much is known about the mechanism of action of vitamin $\mathrm{D}$ [34]. Moreover it is also not known whether all cancer types respond equally to vitamin D treatment. This information is required urgently as cancer cell lines representing carcinomas of breast, cervix and colon and rectum vary in the expression of $\mathrm{Nrf2}$, a known target of vitamin $D$ [35]. On top of this cell to cell variation in the Nrf2 expression, the cellular Nrf2 levels also vary in response to oxidative stress status, which further influenced by the amount of glucose available in the medium [35]. Therefore, it is important to assess the efficacy of vitamin $\mathrm{D}$ in the presence or absence of glucose for inhibitingthese cancer cell lines growth.

Data from our studies showed that vitamin D retarded the growth of colorectal cancer cell line HCT116 more effectively compared to
MCF7 and HeLa. Even though vitamin D reduced the cell growth in the presence of glucose the effect is more when the media is devoid of glucose as Nrf2 is inhibited by vitamin D treatment only in the absence of glucose. Interestingly, vitamin $\mathrm{D}$ inhibited the activity of NQO1, a target gene of Nrf2, more effectively in the absence of glucose. NQO1 is required for cancer cells growth as it helps in the recycling of NAD and NADP co-enzymes [35]. These co-enzymes are essential for continuing key pathways that utilize glucose such as glycolysis and HMP [36]. Since these glucose-metabolizing pathways are heavily utilized by rapidly growing cancer cells, inhibition of NQO1 results in growth retardation of cancer cells. Prior studies have demonstrated the utility of NQO1 inhibitors such as dicoumarol for retarding the cancer cells development [37]. Cell growth inhibition observed by vitamin $\mathrm{D}$ treatment in the presence of glucose is probably due to the effect on multiple other signaling cascades regulating cancer cells viability and survival. For example, vitamin D is a known inhibitor of MAPK signaling cascade. MAPK regulates cell proliferation by promoting cyclin D1 levels in cancer cells [38]. Many other studies determining the efficacy of MAPK inhibitors have shown anti-cancer activity indicating MAPK signaling members are good therapeutic targets [38].

Even though we have made an attempt to determine the efficacy of vitamin D on cancer cells representing carcinomas of breast, colon and rectum and cervix, this study require additional data to conclusively explain: (a) the variations in the efficacy of vitamin D; (b) the influence of glucose on vitamin D potency; (c) whether Nrf2 inhibition by 
Citation: Shruthi N, Prashanthkumar MV, Venugopalreddy B, Suma MN, Subba Rao VM (2017) Analysis of the Cytotoxic Effects of Vitamin D3 on Colorectal, Breast and Cervical Carcinoma Cell Lines. Biochem Anal Biochem 6: 318. doi: 10.4172/2161-1009.1000318
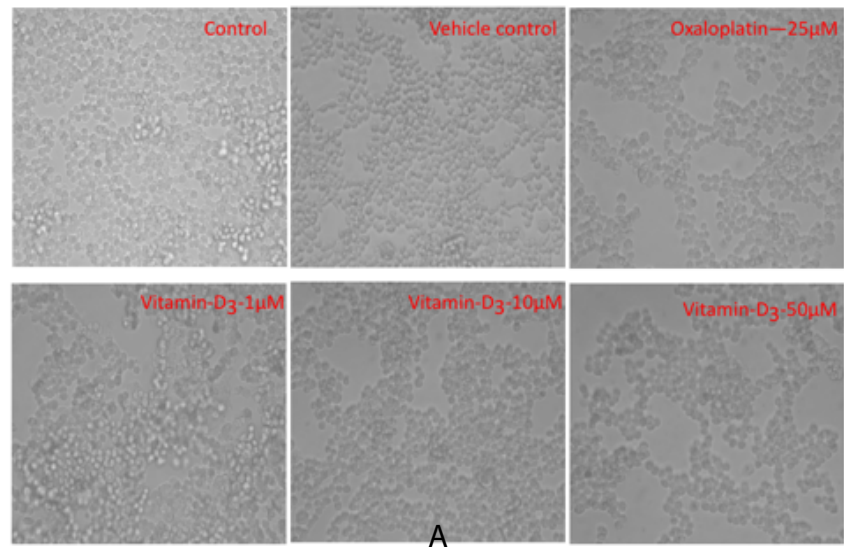

Figure 5: Vitamin D3 retards the proliferation of HCT116 cells in a glucose dependent manner: To assess the differences in efficacy of vitamin D3 when cells were treated in medium or PBS containing glucose or no glucose, respectively, HCT116 cells were plated in 6-well plates and exposed to increasing concentration of vitamin D3 for $6 \mathrm{~h}$. Photomicrographs showed decreased rounded cells only in cells treated with vitamin D3 diluted in PBS containing no glucose. Oxaliplatin (25 $\mu$ M) was used as positive control in this study.

5A: HCT116 treated with vitamin D for $6 \mathrm{~h}-$ Growth medium DMEM with $4.5 \mathrm{~g} / \mathrm{L}$ glucose and treatment medium PBS without glucose.

5B: HCT116 treated with vitamin D for $6 \mathrm{~h}$ - Growth and treatment medium - DMEM with $4.5 \mathrm{~g} / \mathrm{L}$ glucose.

vitamin $\mathrm{D}$ is the key mechanism responsible for growth retardation. Hence future studies should focus on addressing these unresolved questions (Figures 4 and 5).

\section{Conclusion}

In conclusion, we have shown that vitamin D3 (a) inhibits the growth of colorectal carcinoma cells more effectively compared to MCF7 and HeLa cell lines; (b) mediated cell growth inhibition is in part due to the downregulation of Nrf2 only in the absence of glucose; (c) induced apoptosis in colorectal carcinoma cell lines.

\section{Acknowledgements}

Authors would like to acknowledge the research support extended by Jagadguru Sri Shivarathreeshwara University, Mysuru, Karnataka, India

\section{References}

1. Hughes DA, Norton R (2009) Vitamin D and respiratory health. Clin Exp Immunol 158: 20-25.

2. Tripkovic L, Lambert H, Hart K, Smith CP, Bucca G, et al. (2012) Comparison of vitamin D2 and vitamin D3 supplementation in raising serum 25-hydroxyvitamin D status: A systematic review and meta-analysis. Am J Clin Nutr 95: 1357-1364.

3. Wacker M, Holick MF (2013) Sunlight and Vitamin D: A global perspective for health. Dermatoendocrinol 5: 51-108.

4. Dauletbaev N, Herscovitch K, Das M, Chen H, Bernier J, et al. (2015) Downregulation of IL-8 by high-dose vitamin $\mathrm{D}$ is specific to hyperinflammatory macrophages and involves mechanisms beyond up-regulation of DUSP1. Br J Pharmacol 172: 4757-4771.

5. Rosen CJ, Adams JS, Bikle DD, Black DM, Demay MB, et al. (2012) The nonskeletal effects of vitamin D: an Endocrine Society scientific statement. Endocr Rev 33: 456-492.

6. Hossein-nezhad A, Holick MF (2013) Vitamin D for health: A global perspective. Mayo Clin Proc 88: 720-755.

7. Jacot W, Firmin N, Roca L, Topart D, Gallet S, et al. (2016) Impact of a tailored oral vitamin $D$ supplementation regimen on serum 25-hydroxyvitamin $D$ levels in early breast cancer patients: A randomized phase III study. Ann Oncol 27: $1235-1241$.

8. Cashman KD (2007) Vitamin D in childhood and adolescence. Postgrad Med J 83: $230-235$

9. Bikle DD (2011) Vitamin D metabolism and function in the skin. Mol Cell Endocrinol 347: 80-89.
10. Harinarayan CV, Ramalakshmi T, Venkataprasad U (2004) High prevalence of low dietary calcium and low vitamin D status in healthy south Indians. Asia Pac J Clin Nutr 13: 359-364.

11. Bandera Merchan B, Morcillo S, Martin-Nunez G, Tinahones FJ, MaciasGonzalez M (2017) The role of vitamin D and VDR in carcinogenesis: Through epidemiology and basic sciences. J Steroid Biochem Mol Biol 167: 203-218.

12. Cardus A, Panizo S, Encinas M, Dolcet X, Gallego C, et al. (2009) 1,25-dihydroxyvitamin D3 regulates VEGF production through a vitamin D response element in the VEGF promoter. Atherosclerosis 204: 85-89.

13. Shi YC, Worton L, Esteban L, Baldock P, Fong C, et al. (2007) Effects of continuous activation of vitamin $\mathrm{D}$ and $\mathrm{Wnt}$ response pathways on osteoblastic proliferation and differentiation. Bone 41: 87-96.

14. Theodoratou E, Tzoulaki I, Zgaga L, loannidis JP (2014) Vitamin D and multiple health outcomes: umbrella review of systematic reviews and meta-analyses of observational studies and randomised trials. BMJ 348: 2035.

15. Moukayed M, Grant WB (2013) Molecular link between vitamin D and cancer prevention. Nutrients 5: 3993-4021.

16. Liby KT, Sporn MB (2012) Synthetic oleanane triterpenoids: multifunctional drugs with a broad range of applications for prevention and treatment of chronic disease. Pharmacol Rev 64: 972-1003.

17. Kesarwani P, Murali AK, Al-Khami AA, Mehrotra S (2013) Redox regulation of T-cell function: from molecular mechanisms to significance in human health and disease. Antioxid Redox Signal 18: 1497-1534.

18. Godoy P, Hewitt NJ, Albrecht U, Andersen ME, Ansari N, et al. (2013) Recent advances in $2 \mathrm{D}$ and $3 \mathrm{D}$ in vitro systems using primary hepatocytes, alternative hepatocyte sources and non-parenchymal liver cells and their use in investigating mechanisms of hepatotoxicity, cell signaling and ADME. Arch Toxicol 87: 1315-1530.

19. Davis-Yadley AH, Malafa MP (2015) Vitamins in pancreatic cancer: a review of underlying mechanisms and future applications. Adv Nutr 6: 774-802.

20. Fajardo AM, MacKenzie DA, Ji M, Deck LM, Vander Jagt DL, et al. (2012) The curcumin analog ca27 down-regulates androgen receptor through an oxidative stress mediated mechanism in human prostate cancer cells. Prostate 72: 612-625.

21. Vital-Reyes VS, Rodriguez-Burford C, Oelschlager DK, Grizzle WE (2006) Cell density influences the effect of celecoxib in two carcinoma cell lines. Biotech Histochem 81: 51-54.

22. Skehan P, Storeng R, Scudiero D, Monks A, McMahon J, et al. (1990) New colorimetric cytotoxicity assay for anticancer-drug screening. J Natl Cancer Inst 82: $1107-1112$

23. Klapkova E, Cepova J, Pechova M, Dunovska K, Kotaska K, et al. (2017) A comparison of four methods (Immunochemistry and HPLC) for determination of 25-(OH)-Vitamin D in postmenopausal women. Clin Lab 63: 385-388. 
Citation: Shruthi N, Prashanthkumar MV, Venugopalreddy B, Suma MN, Subba Rao VM (2017) Analysis of the Cytotoxic Effects of Vitamin D3 on Colorectal, Breast and Cervical Carcinoma Cell Lines. Biochem Anal Biochem 6: 318. doi: 10.4172/2161-1009.1000318

24. Shailasree S, Venkataramana M, Niranjana SR, Prakash HS (2015) Cytotoxic effect of $\mathrm{p}$-Coumaric acid on neuroblastoma, N2a cell via generation of reactive oxygen species leading to dysfunction of mitochondria inducing apoptosis and autophagy. Mol Neurobiol 51: 119-130.

25. Chomczynski P, Sacchi N (2006) The single-step method of RNA isolation by acid guanidinium thiocyanate-phenol-chloroform extraction: twenty-something years on. Nat Protoc 1: 581-585.

26. Schmittgen TD, Livak KJ (2008) Analyzing real-time PCR data by the comparative $\mathrm{C}(\mathrm{T})$ method. Nat Protoc 3: 1101-1108.

27. Zou X, Gao J, Zheng Y, Wang X, Chen C, et al. (2014) Zeaxanthin induces Nrf2mediated phase II enzymes in protection of cell death. Cell Death Dis 5: 1218

28. Seng S, Avraham HK, Birrane G, Jiang S, Li H, et al. (2009) NRP/B mutations impair Nrf2-dependent NQO1 induction in human primary brain tumors. Oncogene 28: 378-389.

29. Lister A, Nedjadi T, Kitteringham NR, Campbell F, Costello E, et al. (2011) Nrf2 is overexpressed in pancreatic cancer: implications for cell proliferation and therapy. Mol Cancer 10: 37

30. Yuan C, Kosewick J, He X, Kozak M, Wang S (2011) Sensitive measurement of serum 1alpha,25-dihydroxyvitamin $D$ by liquid chromatography/tandem mass spectrometry after removing interference with immunoaffinity extraction. Rapid Commun Mass Spectrom 25: 1241-1249.

31. Bobilev I, Novik V, Levi I, Shpilberg O, Levy J, et al. (2011) The Nrf2 transcription factor is a positive regulator of myeloid differentiation of acute myeloid leukemia cells. Cancer Biol Ther 11: 317-329.

32. Xu L, Badr MZ (1999) Enhanced potential for oxidative stress in hyperinsulinemic rats: imbalance between hepatic peroxisomal hydrogen peroxide production and decomposition due to hyperinsulinemia. Horm Metab Res 31: 278-282.

33. Li MX, Li LF, Zhang L, Xiao ZG, Shen J, et al. (2017) Vitamin D and cancer stem cells in the gastrointestinal tract. Curr Med Chem.

34. Garcia-Quiroz J, Garcia-Becerra R, Santos-Martinez N, Avila E, Larrea F, et al. (2016) Calcitriol stimulates gene expression of cathelicidin antimicrobial peptide in breast cancer cells with different phenotype. J Biomed Sci 23: 78.

35. Teixeira TM, Da Costa DC, Resende AC, Soulage CO, Bezerra FF, et al (2017) Activation of Nrf2-antioxidant signaling by 1,25-Dihydroxycholecalciferol prevents leptin-induced oxidative stress and inflammation in human endothelial cells. J Nutr 147: 506-513.

36. Bovilla VPM, Natraj SM, Srinivasan A, Madhunapantula SRV (2017) Therapeutic potential of targeting Nrf-2-Keap-1 signaling in breast cancers. $J$ Drug Des Re 4: 1038-1051.

37. Liu HY, Li QR, Cheng XF, Wang GJ, Hao HP (2016) NAMPT inhibition synergizes with NQO1-targeting agents in inducing apoptotic cell death in nonsmall cell lung cancer cells. Chin J Nat Med 14: 582-589.

38. Hidaka M, Wakabayashi I, Takeda Y, Fukuzawa K (2013) Vitamin D(3) derivatives increase soluble CD14 release through ERK1/2 activation and decrease IL-8 production in intestinal epithelial cells. Eur J Pharmacol 721 305-312. 